\title{
Disinfectants Material Effectiveness in Reducing Microorganisms on Radiographic Cassettes
}

\author{
Dartini , Yeti Kartikasari, A. Haris Sulistyadi, Asri Indah Aryani, Bagus Dwi Handoko, Panji \\ Wibowo Nurcahyo \\ Politeknik Kesehatan, Kemenkes Semarang, Jl. Tirto Agung Pedalangan, Banyumanik, Semarang 50239, Indonesia. \\ *Corresponding Author: Dartini, Politeknik Kesehatan, Kemenkes Semarang, Jl. Tirto Agung \\ Pedalangan, Banyumanik, Semarang 50239, Indonesia
}

Received: May 27, 2017

Accepted: June 6, 2017

Published: June 9, 2017

\begin{abstract}
Introduction: Radiographic cassette consists of aluminum or steel frame covered by carbon fiber where it's the main function is to protect imaging plate inside. Previous research had found out that radiographic cassette contained microorganisms and Fungi. The numbers of microorganisms and fungi decrease after it's cleaned by a-70\%-alcohol but alcohol is too costly to be a disinfectant.
\end{abstract}

Objective: This research is aimed at identifying the microorganism numbers on radiographic cassette before and after cleaning by $70 \%$ alcohol, lysol, chlorine, and anti-bacterial soap as well as to reveal which disinfectant substance that has the greatest percentage in reducing the microorganisms.

Methods: The numbers of the microorganism (ALT, Staphylococcus, and Fungi) on 13 radiographic cassettes were counted using swab method before and after being cleaned with $70 \%$ alcohol, chlorine solution, lysol, anti-bacterial soap. Data were analyzed descriptively to describe the declining level and determine the greatest reduction.

Result: The results showed that declining level percentage were $65.67 \%$ (chlorine solution), 63,67 \% (alcohol 70\%), 0,33\% (lysol) and $54.33 \%$ (anti-bacterial soap) respectively.

Conclusion: Chlorine solution can be used as a disinfectant to clean the cassette as the alternative of a-70\% - alcohol which is too costly but the effect is not as strong as the chlorine solution.

Keywords: Alcohol, chlorine solution, microorganism, disinfectant, radiographic cassette

\section{INTRODUCTION}

Nowadays, the equipment for making radiographs consists of imaging plate tapes, imaging plates, grids, fixation tools, protective devices and markers that can become a means of radiographic accessory can be a source of bacteria ( Tugwell \& Maddison, 2011).

The cassette consists of aluminum or steel frame with a tube side made of the carbon fiber. The back of the cassette is a thin part of lead to absorb the scattered radiation. The main function of the tape is to protect the imaging plate, not to control the light. Labels coded with numbers indicate the identity of the tape which makes easier to match each cassette with the patient's identity and examination as well as positioning information (Ballinger, 2003). Cassettes are easily destroyed by a fall or collision which may result in damage to the imaging plate inside that the tapes should be checked and cleaned regularly. Checking the tape should be done every time by examining, servicing, or maintaining on a regular basis (Kepmenkes RI,2009)

According to Kepmenkes ( 2007) on the standard of radiographer profession, one of the tasks of radiographers in the field of radiology service is to manage the equipment of radiology and radiotherapy particularly maintaining the radiology equipment, infrastructure, and equipment within the limits of their authorities that will greatly determine the quality of service delivery. The maintenance includes hygiene and maintenance of CR cassettes as radiology the effort and action of radiology quality assurance.

The procedure or activity of X-ray tape caring and cleaning in some of the existing literature, mostly aimed at, among others, avoiding the 
tapes of objects or materials that can interfere with the quality of radiographs such as the appearance of artifacts. But researchers argue that the cassette cleaning activity can also contribute to minimizing the microorganisms that may be present in X-ray tapes due to the facts that the tapes are used repeatedly to different patients. Judging from the usage, the tape can be an infectious medium in which microorganisms that may exist in one patient and the other may be attached to the cassette after radiological examination took place.

This is supported by previous research that the tapes contain microorganisms and fungi (Laili, 2013). In addition, research conducted by Dartini (2013) found out the decrease in the content of microorganisms and fungi on tapes after being cleaned with a-70\%-alcohol. However, input from hospitals related to the use of alcohol as a disinfectant material that this is quite expensive making difficult to procure as a disinfectant to clean the tape.

Based on the above background, researchers are interested in examining other disinfectant materials as an alternative to clean the tapes from contamination of microorganisms by comparing its effectiveness. The benefit of this research is to disseminate the knowledge about the importance of cleaning imaging plate tapes by using affordable disinfectants but with the ability to eliminate the highest microorganisms and also as inputs for hospital radiographers on effective and affordable disinfectant materials.

\section{MATERIALS AND METHODS}

This is an experimental research with pre and post treatment approach. The research design is depicted in the following figure.

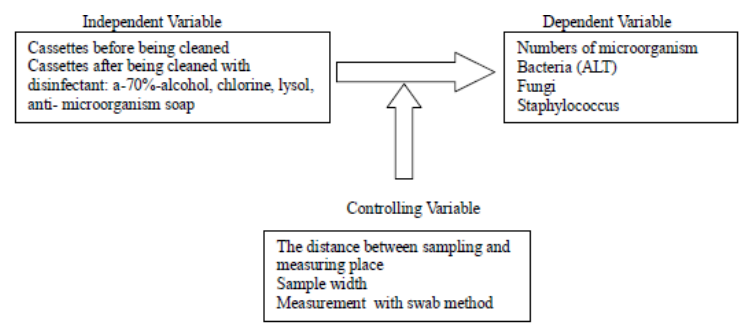

Figure1..Research Design

The sample is the whole 13 imaging plate tapes where the method of taking data is with swab test on the imaging plate before and after the tape is cleaned with lysol, alcohol, anti-bacterial soap and chlorine. Data is analyzed descriptively.

\section{RESULTS AND DISCUSSIONS}

The results of counting and percentage reduction of ALT, staphylococcus, and fungi on cassette surface before and after cleaning with lysol, alcohol, chlorine, and anti-bacterial soap are shown in the following tables.

Table1. Microorganism in Imaging Plate Before and After Cleansing with Various Disinfectant

\begin{tabular}{|c|c|c|c|c|c|c|c|}
\hline No & $\begin{array}{l}\text { Disinf } \\
\text { ectants }\end{array}$ & $\begin{array}{l}\text { Treat } \\
\text { ment }\end{array}$ & Mean & $\begin{array}{l}\text { Med } \\
\text { ian }\end{array}$ & $\begin{array}{l}\text { Maxi } \\
\text { mum }\end{array}$ & $\begin{array}{l}\text { Mini } \\
\text { mum }\end{array}$ & SD \\
\hline \multirow[t]{3}{*}{1} & \multirow[t]{3}{*}{ Lysol } & Befor & 22191 & 6,93 & 121,6 & 625 & 35180 \\
\hline & & & .692 & 3 & 35 & & .085 \\
\hline & & After & $\begin{array}{l}230.0 \\
77\end{array}$ & 133 & 863 & 0 & $\begin{array}{l}260.2 \\
64\end{array}$ \\
\hline \multirow[t]{3}{*}{2} & \multirow{3}{*}{$\begin{array}{l}\text { Alcoh } \\
\text { ol }\end{array}$} & Befor & 29660 & $\begin{array}{l}8,12 \\
5\end{array}$ & $\begin{array}{l}292,1 \\
14\end{array}$ & 1067 & 78931 \\
\hline & & After & 3368 & 237 & 1919 & 70 & 4873 \\
\hline & & & 00 & & & & 68 \\
\hline \multirow[t]{3}{*}{3} & \multirow[t]{3}{*}{ Soap } & Befor & 11421 & 216 & 65109 & 480 & 17663 \\
\hline & & & .200 & 0 & & & .219 \\
\hline & & After & $\begin{array}{l}85240 \\
0\end{array}$ & 216 & 6727 & 128 & $\begin{array}{l}1677 . \\
034\end{array}$ \\
\hline \multirow[t]{4}{*}{4} & \multirow{4}{*}{$\begin{array}{l}\text { Chlori } \\
\text { ne }\end{array}$} & Befor & 13352 & 104 & 38250 & 812 & 12582 \\
\hline & & & .200 & 41 & & & .567 \\
\hline & & After & 585 & 269 & 2705 & 69 & 717.8 \\
\hline & & & & & & & \\
\hline
\end{tabular}

Table 2. Staphylococcus in Imaging Plate Before and After Cleansing with Various Disinfectant

\begin{tabular}{|c|c|c|c|c|c|c|c|}
\hline No & $\begin{array}{l}\text { Disinf } \\
\text { ectants }\end{array}$ & $\begin{array}{l}\text { Treat } \\
\text { ment }\end{array}$ & Mean & \begin{tabular}{|l} 
Med \\
ian
\end{tabular} & $\begin{array}{l}\text { Maxi } \\
\text { mum }\end{array}$ & $\begin{array}{l}\text { Mini } \\
\text { mum }\end{array}$ & SD \\
\hline \multirow[t]{2}{*}{1} & \multirow[t]{2}{*}{ Lysol } & $\begin{array}{l}\text { Befor } \\
\mathrm{e}\end{array}$ & 84 & 54 & 484 & 0 & $\begin{array}{l}128.4 \\
28\end{array}$ \\
\hline & & After & $\begin{array}{l}22.76 \\
9\end{array}$ & 10 & 172 & 0 & $\begin{array}{l}45.62 \\
4\end{array}$ \\
\hline \multirow[t]{2}{*}{2} & \multirow[t]{2}{*}{$\begin{array}{l}\text { Alcoh } \\
\text { ol }\end{array}$} & $\begin{array}{l}\text { Befor } \\
\text { e }\end{array}$ & $\begin{array}{l}2067 . \\
667\end{array}$ & $\begin{array}{l}1.23 \\
4\end{array}$ & 11000 & 53 & $\begin{array}{l}1237 . \\
330\end{array}$ \\
\hline & & After & 34 & 21 & 144 & 0 & $\begin{array}{l}43.10 \\
3\end{array}$ \\
\hline \multirow[t]{2}{*}{3} & \multirow[t]{2}{*}{ Soap } & $\begin{array}{l}\text { Befor } \\
\text { e }\end{array}$ & $\begin{array}{l}1614 . \\
467\end{array}$ & 756 & 6240 & 53 & $\begin{array}{l}1761 . \\
975\end{array}$ \\
\hline & & After & $\begin{array}{l}61.40 \\
0\end{array}$ & 49 & 205 & 0 & $\begin{array}{l}52.06 \\
4\end{array}$ \\
\hline \multirow[t]{2}{*}{4} & \multirow[t]{2}{*}{$\begin{array}{l}\text { Chlori } \\
\text { ne }\end{array}$} & \begin{tabular}{|l} 
Befor \\
$\mathrm{e}$
\end{tabular} & $\begin{array}{l}3786 . \\
067\end{array}$ & $\begin{array}{l}3,85 \\
7\end{array}$ & 7507 & 0 & $\begin{array}{l}2622 . \\
729 \\
\end{array}$ \\
\hline & & After & $\begin{array}{l}94.66 \\
7\end{array}$ & 103 & 274 & 5 & $\begin{array}{l}69.80 \\
0\end{array}$ \\
\hline
\end{tabular}

Table3. Fungi in Imaging Plate Before and After Cleansing with Various Disinfectant

\begin{tabular}{|c|c|c|c|c|c|c|c|}
\hline No & $\begin{array}{l}\text { Disinf } \\
\text { ectants }\end{array}$ & $\begin{array}{l}\text { Treat } \\
\text { ment }\end{array}$ & Mean & $\begin{array}{l}\text { Med } \\
\text { ian }\end{array}$ & $\begin{array}{l}\text { Maxi } \\
\text { mum }\end{array}$ & $\begin{array}{l}\text { Mini } \\
\text { mum }\end{array}$ & SD \\
\hline \multirow[t]{2}{*}{1} & \multirow[t]{2}{*}{ Lysol } & $\begin{array}{l}\text { Befor } \\
\mathrm{e}\end{array}$ & $\begin{array}{l}1005 . \\
615\end{array}$ & 0 & 5143 & 0 & $\begin{array}{l}1689 . \\
883\end{array}$ \\
\hline & & After & 0.769 & 0 & 5 & 0 & 1.878 \\
\hline \multirow[t]{2}{*}{2} & \multirow[t]{2}{*}{$\begin{array}{l}\text { Alcoh } \\
\text { ol }\end{array}$} & $\begin{array}{l}\text { Befor } \\
\mathrm{e}\end{array}$ & 0,000 & 0 & 0 & 0 & 0.000 \\
\hline & & After & 4.400 & 0 & 27 & 0 & 9.979 \\
\hline \multirow[t]{2}{*}{3} & \multirow[t]{2}{*}{ Soap } & $\begin{array}{l}\text { Befor } \\
\text { e }\end{array}$ & 3.600 & 0 & 54 & 0 & $\begin{array}{l}13.94 \\
3\end{array}$ \\
\hline & & After & 2.133 & 0 & 21 & 0 & 6.566 \\
\hline \multirow[t]{2}{*}{4} & \multirow[t]{2}{*}{$\begin{array}{l}\text { Chlori } \\
\text { ne }\end{array}$} & $\begin{array}{l}\text { Befor } \\
\mathrm{e}\end{array}$ & 11 & 0 & 134 & 0 & $\begin{array}{l}34.95 \\
1\end{array}$ \\
\hline & & After & 5.333 & 0 & 38 & 0 & $\begin{array}{l}11.80 \\
0\end{array}$ \\
\hline
\end{tabular}


The reduction percentage of the number of microorganisms before and after cleansing with various kinds of disinfectant can be seen in Figure 2 below.

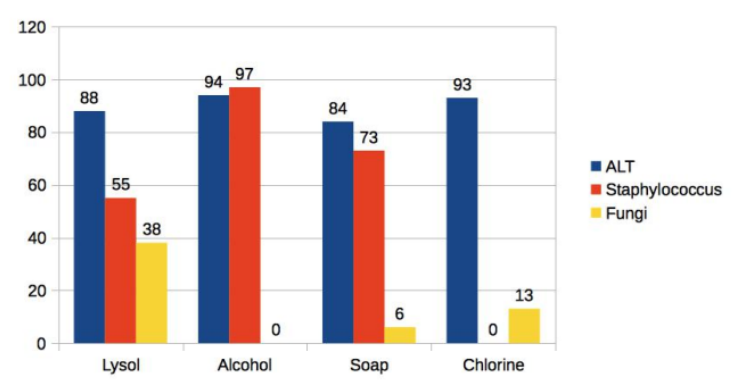

Figure2. Microorganism Reduction Percentage in Imaging Plate After Cleansing with Various Disinfectant

The table indicated that the average yield of ALT, staphylococcus, and fungi before cleansing with lysol was 22191.692; 884.000; 1005,615, with alcohol was 29660.000; 2067.667; 0.000, with anti-bacterial soap was $11421.200 ; 1614.467 ; 3.600$, and with chlorine was $13352.200 ; 3786.067$; and 11 respectively. Furthermore, the mean yields of ALT, staphylococcus, and fungi after cleansing with lysol were $230.077 ; 22,769 ; 0.0769$, with an alcohol was $336.800 ; 34.000 ; 4.400$, with antibacterial soap was: $852.400 ; 61.400 ; 2,133$, and with chlorine was: 585; 9.667; and 5.333. The test results revealed that the average percentage of the decrease in the number of microorganisms in various disinfectants sorted from the highest: chlorine $=65.67 \%$, alcohol $=$ $63.67 \%$, lysol $=60.33 \%$ and the lowest antibacterial soap $=54.33 \%$.

These results become evident that by cleaning the imaging plate using lysol, alcohol, antibacterial soap and chlorine can reduce the microorganism content especially for ALT and staphylococcus on the surface of the tape. According to Darmadi (2008), control of nosocomial infections can be done by sterilizing the tools used. Disinfectants used to clean the imaging plates of lysol, alcohol, soap and chlorine serve to eliminate or to reduce the number of microorganisms on the surface of the imaging plate, thus reducing the likelihood of nosocomial infection among patients with patients and also among patients with workers in radiology. Lysol (phenol compounds) according to Sumawinata (2003), can decrease the number of microorganisms by destroying the cell wall and precipitation of cell proteins from microorganisms resulting in coagulation and malfunction in these microorganisms. Alcohol disinfectants can reduce the number of microorganisms by denaturing the protein by dehydration and dissolving the fat so that cell membranes are damaged and enzymes will be activated by alcohol (Darmadi, 2008). Chlorine can reduce the number of microorganisms by inhibiting the oxidation of glucose in the cells of microorganisms by blocking the enzymes involved in carbohydrate metabolism. The advantages of this disinfectant are easy to use, and the types of microorganisms that can be killed with these compounds are also quite extensive, including gram-positive bacteria and gram-negative bacteria (Purnawijaya, 2001).

\section{CONClusion}

Different ways of working on each disinfectant result in the differences of the ability to reduce or to eliminate microorganisms on the imaging plate surface. Chlorine is a disinfectant with the highest ability in reducing the number of microorganisms to be a good alternative for hospitals, especially radiology installations in an attempt to decrease the incidence of nosocomial infections. Chlorine solution is very easy to obtain and the price is relatively cheaper than alcohol or antibacterial soap beside the weakness for being toxicful and smells unpleasant.

\section{REFERENCES}

[1] Ballinger, Philip W. dan Eugene D. Frank. 2003. Merrill's Atlas of Radiographic Positions and Radiologic Prosedures, Tenth Edition, Volume Three. Saint Louis : Mosby

[2] Darmadi, 2008, Infeksi Nosokomial: Problematika Dan Pengendaliannya, Jakarta, Penerbit Salemba Medika.

[3] Dartini, 2013, Analisis perbedaan Mikroorganisme yang terdapat pada kaset sinar-x sebelum dan sesudah dibersihkan di Rumah sakit, Poltekkes Kemenkes Semarang.

[4] Keputusan Menteri Kesehatan Republik Indonesia Nomor: 375/Menkes/SK/III/2007 Tentang Standar Profesi Radiografer.

[5] Keputusan Menteri Kesehatan Republik Indonesia Nomor:. 1250/Menkes/SK/XII/2009 Tentang Pedoman Kendali Mutu (Quality Control) Peralatan Radiodiagnostik.

[6] Laili, Nuriski, 2013, Analisis mikroorganisme yang terdapat pada kaset sinar-x di Instalasi radiolog, Prodi D-III Teknik Radiodiagnostik dan Radioterapi Purwokerto.

[7] Purnawijayanti HA, 2001, Sanitasi, Higiene dan Keselamatan Kerja dalam Pengolahan Makanan, Yogyakarta, Penerbit Kanisius 
[8] Sumawinata N,. 2003, Senarai Istilah Kedokteran Gigi, Indonesia, Penerbit Buku Kedokteran EGC
[9] Tugwell, J. and Maddison, A., 2011. Radiographic markers $-A$ reservoir for bacteria?. Radiography, 17(2), pp.115-120.

Citation: Dartini et al, Disinfectants Material Effectiveness in Reducing Microorganisms on Radiographic Cassettes.ARC Journal of Public Health and Community Medicine. 2017; 2(2):15-18. doi:dx.doi.org/10.20431/2456-0596.0202002.

Copyright: (C) 2017 Authors. This is an open-access article distributed under the terms of the Creative Commons Attribution License, which permits unrestricted use, distribution, and reproduction in any medium, provided the original author and source are credited. 